\title{
LOOKING BEYOND THE TRIBE: ABANDONING PARADIGMS TO WRITE SOCIAL HISTORY IN YEMEN DURING WORLD WAR I
}

\author{
Isa Blumi*
}

\begin{abstract}
A common error in historico-political analysis consists in an inability to find the correct relation between what is organic and what is conjunctural. This leads to presenting causes as immediately operative which in fact only operate indirectly, or to asserting that the immediate causes are the only effective ones ... In the first case there is an overestimation of mechanical causes, in the second an exaggeration of the voluntarist and individual element (Gramsci 1971, p. 178).
\end{abstract}

\section{Introduction $^{1}$}

Circulating in Turkey today are scores of lingering images of Yemen taken primarily from the context of a rebellion in which Anatolian soldiers died in a far-off periphery of the Ottoman Empire. Crudely situated in such a context, Yemen's position in the disciplines studying the Middle East has suffered from this perception of marginality. As a result, Yemen's "tribal society" has been relegated to the works of anthropologists, leaving unacknowledged its significance to nineteenth- and early-twentieth-century history.

I suggest this is true, to an extent, because many historians have failed to read their sources critically. As Prakash (1995) has suggested, the flirtation with nineteenth-century positivism was not a monopoly of the "West." The Ottoman state certainly had its own understanding of imperial order, which was reflected in its domains, including Yemen. This understanding of how Ottoman order was applied to its

\footnotetext{
* New York University, Joint History and Middle Eastern Studies Program, New York City

1 The author would like to thank the staffs of the Prime Minister's Archives in Istanbul (BBA) and the Public Records office at Kew (PRO) for their assistance. Thanks are also extended to the participants of the roundtable discussion held at Koç University in Istanbul in 1998, and especially to its organizer, Nicole Van Os, and to the anonymous reader for her/his comments. Portions of this paper have been written with the help of funding from USIS provided by the American Research Institute in Turkey.
}

New Perspectives on Turkey, Spring 2000, 22, pp. 117-143 
subject populations has left its mark. As a consequence, there is an interesting link between that period and our own. In the works of social scientists and historians today, a lingering artifact of an imperial vernacular has found its roots. This has cost historians of the Ottoman Empire precious time in exploring the depths of the inner logic of imperialism and the impact it had on societies around the world. The lingering stereotypes of Yemen, in particular, are not harmless archaisms for Ottoman, Middle Eastern, and imperial historians. They clearly permeate both the general public's uncritical understanding of the world and an academic community that has done little to counter the cross-cultural translations of places such as Yemen that often inform the media (Blumi 1998). The following article seeks to engage the literature dealing with Yemen, a body of work that has limped into the twenty-first century, carrying with it a largely uncritical application of tools no longer deemed appropriate in more robust academic circles. In identifying as problematic the essentialism that has, by and large, been unchallenged by historians of earlier generations, it is hoped we can begin to assert a critical approach to such seemingly unimportant places in order to make more meaningful historical claims about the Ottoman Empire.

\section{Ottoman Yemen}

Situated in the heart of a crossroads of trade routes and geostrategic hot spots, Yemen represented a vital interest for a number of imperial powers at the turn-of-the twentieth century. For Istanbul, a number of economic schemes with military implications-as suggested by the project to extend the Hijaz Railway to Yemen's port of Hudeydedemonstrate that the Ottoman Empire had aspirations to maintain influence in the important trade routes that passed through the Red Sea. It must be noted that the social, economic, and political diversity of the region-coupled with contradictory imperial projects on both sides of the Red Sea and their hinterland-serves as a clear example of the complexity of the area for historians of the period. ${ }^{2}$ Unfortunately, the literature that studies imperial rivalries in the area has taken a

2 The study of Italian interests in Yemen has been virtually ignored and deserves far greater research in order to understand their impact on a number of issues raised below. For a fair study on Italian interests in the Red Sea region, see Lenci 1990, and for a brief look at Yemen during the period, see Baldry 1976. 
decidedly externalist perspective, ignoring local factors by failing to integrate local communities into the narrative. Rather than explore the internal tensions and administrative reactions to local communities, most studies resort to implying that whole populations were hapless pawns in the manipulations of the Great Powers struggling to control access to the Suez Canal and the route to Asia (Anscombe 1997; 'Uthman Abãzah 1987).

The power of imperial states and their systems of fiscal reform, investments in infrastructure, telegraph lines, and military barracks, such as those introduced by Istanbul after the 1870 s, transformed aspects of life in places such as Yemen. It is a mistake, however, to cite administrative transformations and imperial intentions without reflection on how local communities reacted to such measures. The underlying assumption in such readings of history between presumably unequal adversaries is that local, indigenous communities were acted upon, and their rigidly formed social structures were incapable of adapting to the variables introduced by a modern state. The unbending, traditional social structures that undergo painful confrontation with modernity simply do not exist beyond the comfortable categories imposed by social scientists and historians.

\section{Social History During War}

World War I has been attracting growing interest among Ottoman historians. Studying the war in conventional ways certainly has its merits for those interested in writing textbooks and teaching introductory courses. But there is a serious need to move beyond narratives of the battle, the dictates of imperial capitals, and descriptions of transitions to post-imperial nation-states. There is a dynamic involved in the culture of war-not only for the men who fought its battles but also for the millions involved in the "periphery" of military strategies and diplomatic pretensions. The concept of total war, for instance, has been claimed as the exclusive property of industrialized societies. However, as the following will demonstrate, what can be read as the transforming historical event that introduced women to the workforce in imperial cities throughout Europe and the Ottoman Empire, has similarly made important contributions to societies decidedly outside the experience of modernity (Maier 1975). World War I, fought between imperial armies (composed of mostly subject 
conscripts), did not simply dictate the terms of change. Jt created a new, often powerful annex to life for many people in the Ottoman Empire (and the rest of the world).

Yemen can offer an important lesson to all of us fixated on the prejudices of the (European) metropole. Societies on the "peripheries" were equally shattered by the total war that fell upon their lives-from neo-slavery in French Africa to the negotiation of political and economic power in Yemen covered here (Echenberg 1991). But these changes did not come solely through measures applied from colonial strategies. They also emerged out of conditions that demand focus on local factors in conjunction with the larger narrative of a world war among imperial powers.

Far from its transparent and idealized image of a historical backwater perfect for, specifically, anthropologists in search of that authentic preserve of a pre-modern Islamic world inhabited by warrior tribes, Yemen proves to be an important case-study of the complexities of daily life in history. ${ }^{3}$ The issue of using analytical categories that reinforce stereotypes of the "Middle East" is addressed here in order to articulate the need for a far more localized historical focus-one that identifies as its horizon not the overarching comprehensive medium but the no less ambitious aspiration of specifying (as opposed to generalizing) the complexity of daily life. Such studies are not absent from the field, but they have largely been ineffectual in directing a wholesale transformation of Ottoman history. Rather, these works have been directed at and appreciated by an audience outside the Middle East (Abu-Lughod 1990; Mundy 1995).

The Ottoman imperial experience serves as an ideal prism through which many of the complexities of Yemeni society can be highlighted and a new approach to studying history can be explored. I carry out my (by no means exhaustive) critique of the literature on Yemen by studying the period immediately following the Da'an treaty of 1911 until the end of World War I. This treaty, signed between representatives of the Yemeni Zaydi community (Imam Yahya in particular) and the Ottoman imperial state, led by the Albanian Marshal Ahmet Izzet

3 The foundational work of E. E. Pritchard, Ernest Gellner, and for different reasons Clifford Geertz, has codified a vocabulary for the anthropologists' trade and set the terms under which, in spite of all efforts to make it fit, any case that appears to be anomalous becomes characterized as such and is treated thus in subsequent work. See, e.g., Anderson 1990. 
Paşa, marks a watershed for the larger arena of Ottoman Yemen. ${ }^{4}$ The treaty formally ended hostilities between the leader of Yemen's dominant sectarian community in the northern areas of the vilayet, and the imperial power claiming sovereignty over the whole of the territory. In return for the imam's cooperation, Istanbul conceded significant local powers to him, including a greater role in adjudicating in accordance with his version of the Shari'a (Ahmet İzzet Paşa 1928; 'Uthman Abāzah 1979, pp. 277-327; Sālim 1971, pp. 135-61). What I will demonstrate in the course of this paper is that İmam Yahya, far from being the dominant Yemeni player, as suggested in modern sources, needed this treaty as much as the Ottomans did, in order to protect his position in local political circles. I have selected this period because it enables me to highlight some of the inherent complexities of Yemeni society at a time when the Ottoman Empire and the Islamic world generally have been depicted as being in a state of decline.

Although the war years have been largely skimmed over in both Arabic and European works, my primary research suggests that the war and its links to imperialism created an interesting compilation of social, political, and economic conditions for the diverse population of the Ottoman territory of Yemen. I am not suggesting, however, that this period represents a break from a more predictable and orderly past and thus reinforces the epistemological assumptions of social scientists and historians fixated on categories. I also do not want to suggest that Ottoman "reforms" introduced into Yemen are reflective of a form of creeping modernity and thus may have created a new "consciousness." Instead, I believe we should see the Ottoman period in Yemen as but a chapter in a continuing process of change, adaptation, and contestation. Sociological patterns that have often been glossed over with crude Weberian and Durkheimian typologies, simplifying Yemen (and Islamic) society generally into neatly identifiable, stable, and unchanging units-city, country, peasant, tribes-prove to be highly fluid. These units of analysis-in the case of Yemen, they are usually

4 The Zaydi community was the dominant Shi'i sect in Yemen whose area of inhabitancy during the late Ottoman period extended from Sana'á' north toward the border with the Hijaz vilayet. The two other prominent sectarian communities in Yemen, the Shafi' Sunnis and the Ismailis, as well as myriad Sufi orders, historically lived under the political domination of Zaydi imams and their armies. When Ottoman troops entered Yemen's mountainous hinterlands in the 1870s, they substantially strengthened the power of such historically persecuted communities and created new dynamics on the ground. 
framed in legal, ideological, and tribal terms-never represent static entities. I will join others in suggesting alternative analytical strategies-starting with the construct of a dynamic and multifaceted empirethat may serve us well in approaching contexts dominated by professional rigidities and powerful provincialisms. ${ }^{5}$

\section{Imperial Contest}

The conventional focus of historians who have attempted to explore Yemen's Ottoman past is a concentration on the imperial aspect of the experience. Imperial policies spanning decades are certainly valid topics of exploration, since a variety of players-Italy, France, Great Britain, and the Ottoman state-became involved in Southern Arabia. Instead, however, I would suggest we adopt Engin Akarl's approach and explore a more internalist approach to researching social and structural transformations in the Ottoman Empire's territories (Akarl 1993). Jon Mandaville has suggested that imperial structures introduced by Istanbul transformed Yemen over the course of some fifty years of nominal rule in the highlands (1984). This is surely the case. After consulting British and Ottoman documents, however, I have found that local factors prove to have been resistant to the predetermined sociological categories that social scientists like to employ in measuring change/stasis. Ottoman efforts to consolidate imperial control of Yemen proved unsuccessful largely because Istanbul's immediate relationship with its subjects as an imperial power did not correspond to realities on the ground. These failures cannot be explained only through simplistic dichotomies distinguishing the native and the imperial administrator. Much more complicated processes occurred, going beyond the imperial mind to the administrative possibilities of empire. What Jon Mandaville and Klaus Kreiser fail to capture in their brief forays into Ottoman Yemen is the decidedly fluid interchange between the state and its subject, something beginning to receive note in the growing field of studies on European imperialism (Kreiser 1989). For instance, the application of Sultan Abdülhamid II's (or Imam Yahya's) dictates on forms of social practice or organization

5 See Beshira Domani's (1995) study for an excellent example of how we should reconfigure our criteria for observing changes in the Ottoman imperial context, and Abou-El-Haj 1991 for a general observation. For a helpful example outside the Middle East, see Raggio 1986. 
often were translated locally to confirm or reconfigure, depending on the situation, both discursive hegemony and the political application of that domination. As will be noted throughout, universalist categories fail to reflect local realities when we abandon the self-affirming logic of their empirical application (Eickelman and Piscatori 1990, p. 20; Asad 1993, pp. 210-11).

Ottoman governance, as read by historians, is a testament of the failure to address the Empire's complex social dynamism. Historians who are fixated on an administrative vernacular that, it is suggested, reflected a plethora of organizational, rigid social models adopted from Europe, miss the issues of application and local responses to them (Findley 1980; Davison 1963). During Abdülhamid II's reign, an extensive, ambitious program of indoctrination was carried out with the intention of settling the Empire's "tribal" peoples. In an effort that has received some scholarly attention, highly dubious sociological constructions, based on loose translations of a European understanding of tribes in the Islamic world, provided the justification for selection of a large number of Yemeni children to attend the Aşiret Mektebi in Istanbul between 1892 and 1902 (Rogan 1996; Akpinar 1997). ${ }^{6}$

The fact that the imperial state attempted to settle categorically marginal actors suggests that markers defining the imperial subject may not have appreciable value to those seeking to analyze the period historically. The failure of the imperial project should inform future research of the very administrative assumptions made by Ottoman bureaucrats and the level of local reaction, which, as mentioned, was far more nuanced than often assumed. Failure to acknowledge the reception of imperial measures in Yemen may disguise the significant fact that local communities were neither easily subjugated nor permanently rebellious (Muhtar Paşa 1996, pp. 40-50).

\section{Tribalism in War: İmam Yahya}

In an attempt to demonstrate the need to move beyond comfortable analytical abstractions (used in the past) that focus almost exclusively on the imperial capital's perspective, I wish to suggest a possible rationale for İmam Yahya's signing the Da'an treaty with the Ottoman state in 1911-a treaty that historians regard as having been offered by

6 For the placement of children of tribal families into the Hamidian Tribal School in Istanbul, see BBA DH.EUM.VRK 20/102 1328.S.22 1/1 
Istanbul out of desperation. A long and expensive (in monetary and manpower terms) war in Yemen with the region's "spiritual leader" at the head of the rebellion set the stage for an analysis that has failed to read into the events and conditions surrounding the treaty. I would suggest that a number of indications point to as-yet-unexplained tensions between the imam's principal allies before 1911, driving him to sign the $\mathrm{Da}$ 'an treaty from a position of weakness-a position that may have been understood by Ottoman officials. This is a significant point, since past interpretations often identified Imam Yahya as the dominant force in Yemen during the signing of the Da'an agreement. The same literature immediately evokes the number of concessions the imam won from the Ottoman state, concessions that purportedly gave him de facto independence (al-Shimāhi 1984, pp. 185-86; al-Wāsi'i 1928, pp. 234, 259; 'Uthman Abāzah 1979, pp. 361-62).

While the agreement explicitly hands over to the imam the right to claim sovereignty over Zaydi lands, it implicitly links the imam's precarious coercive power to the Ottoman army. It is clear from documents that before and after the agreement, the imam was in dire need of military assistance in his battles with local adversaries. ${ }^{7}$ In fact, he elicited Ottoman support as early as 1907 , only to be rebuked by a mili-tant Istanbul seeking complete submission (Mehra 1988, p. 47). I suggest that persistent rivalries within his assumed constituency; the threatening figure of Muhammad İdrisi, a rival in the neighboring region of 'Asir; and the emergence of the British as a regional player convinced Yahya that he had little option but to end his dangerous struggle with the Ottoman state. By focusing on İdrisi, who will be discussed below, and the persistent local rivalries that render obsolete the comfortable categories-tribal honor codes, kinship, and sectarian identity-used in the literature, we see that the imam did not command automatic hegemony over Zaydi Yemen. Some would suggest that Yahya commanded religious legitimacy, as imam, and the acceptance of his call for a "Jihad" on the British is evidence of his overarching

7 A document attests to defiance emerging at the time among his supposed Zaydi subjects: a letter from İmam Yahya to Sharif Husayn bin Muhammad al Dhamin and his general, accusing several shaykhs from the Jawf region of not acknowledging the imam's sovereignty over the area. The letter clearly states that the imam's sovereignty over Jawf was solidified in a signed agreement (read: treaty) between the parties in question. Such a breach of agreement is indicative of Imam Yahya's limited control over many regions before his alliance with Istanbul. Dated 19, Month [?] 1332 (private collection). 
control of Yemeni politics (Kruse 1984). The fixation, however, on the political/cultural unit-the imam-unfortunately does not accord well with the realities.

The fact that a number of the imam's constituents became his violent opponents did not necessarily mean they could muster an effective, unified alliance against him (Blumi 2000). Three different factions emerged by 1912 , each making separate claims to the seat of the imam (Sālim 1971, p. 137). These groups were not united, and they fought among themselves as much as with the imam and the Ottomans. ${ }^{8}$ These complications are fully understandable when reflecting on factors involved. These groups all solicited outside assistance and, judging from the plethora of bidders, often with contradictory agendas (Ottomans, Italians, British, and Muhammad İdrisi), it is little wonder that efforts to undermine the imam had no central focus. World War I and the number of outside players it introduced can be considered a significant indicator of how transformative such historical events can be for local histories.

Reasons for opposition to İmam Yahya were numerous. I suggest that the imam attempted to sidetrack local channels of engaging challengers whom he could not eliminate on his own. As a consequence, Yahya sought absolute hegemony over the area by using the Ottoman army, which was at his disposal after the treaty. The imam's enhanced military power after the treaty fostered greater antagonism as less and less interchange took place among communities. In short, the pursuit of day-to-day politics reflected more of an imposition of the imam's military-backed dictates rather than mutual exchange. The period in question reveals a dramatic increase in small-scale violence in response to Yahya's abuse of power. Clashes between Ottoman troops attached to Imam Yahya's own forces and resistant Zaydi elements are the most obvious indicators of the failure of Imam Yahya to gain control over the Zaydis after the accords. Such violence also proves to be a key window into the imam's strategies behind forming an alliance with

8 The British in 'Aden complained that tied to these factors were an assortment of secondary impediments to a coherent resistance: the constant profitmaking of shaykhs and their constituents and diverse local power relations translated into destructive localized rivalries. These small-scale, personalized rivalries clearly demonstrate the questionable value of universal terms in analyzing opposition to the Ottoman state. Report to General Sir Reginald Wingate, High Commissioner, Cairo, from J. H. Stewert, Aden Protectorate, 7 September 1917 (Ingrams 1993, p. 182). 
the Ottoman state: With the Ottoman army he could exert greater power over his constituencies. ${ }^{9}$

As the fractured challenge to İmam Yahya's assumed authority grew, and his own constituent resources diminished through defections, the imam's dependence on the Ottoman state increased accordingly (Ingrams 1993, p. 64). It is evident that the imam soon identified the Ottoman army as a defensive barrier to his ever-larger number of enemies. I would suggest that this recognition occurred before he signed the 1911 treaty but only manifested itself during World War I. Throughout the war, the imam was reported to have diverted large numbers of Ottoman soldiers (intended for defensive purposes) and pitted them against his warring rivals, essentially keeping them away from both the northern and the southern fronts with Britain. ${ }^{10}$ This caused major problems for the Ottomans in their efforts to resist the British and their allies in the Hijaz. Mahmud Nadim, the Syrian-born governor of Yemen, and Imam Yahya often squabbled over the allocation of Ottoman troops. In August 1914, for instance, Nadim had ordered 2,000 troops stationed in the North to return to Sana'a' in order to better press a vulnerable British position in the South. The imam refused, however, to allow 1,500 of them to leave their barracks, demanding they stay to help fight his battles against disloyal subjects. ${ }^{11}$ Such levels of military fusion indicate the imam's deep anxiety over his power-an anxiety that translated into his long-term alliances with a faltering empire.

There are several reasons for Imam Yahya's reluctance to abandon an Ottoman state whose fortunes clearly began to take a negative turn over the course of the war. Essentially, the imam could not trust the

9 There is documentary evidence of the imam's attacking Zaydi shaykhs who were in the midst of battling with Ottoman troops. For example, the imam specifically identifies the 'Arhab (Bakil section from an area around Sana'a') as targets for the imam's troops because of their continuous actions against the Ottoman state. Acts such as these certainly convinced many people of the imam's true sentiments. İmam Yahya to his general, 1330 (Abu Ghanim 1990, p. 476).

10 In order to assuage the panicked imam, the Ottomans withdrew troops from the front with Idrisi to protect the imam at Shahara, his headquarters, from attacks by Zaydi opponents. Such realities clearly put a strain on the Ottoman Empire's ability to fight a war along the southern front. Report to General Sir Reginald Wingate, High Commissioner, Cairo, from J. H. Stewert, Aden Protectorate, 7 September 1917 (Ingrams 1993, p. 181).

11 Letter from Sultan 'Ali Bin 'Ali of Abdali, 19 August 1914. No. 119, to Colonel H. F. Jacobs in 33rd Weekly letter from Aden Residency, PRO FO $78 / 53785$. 
intentions of the British. Over the years, the influence of the British over neighboring areas had grown, and large amounts of money and weapons had found their way to the imam's potential rivals. The imam's mistrust had been compounded whenever the British attacked Ottoman positions in what the imam considered his political domain, for each time the British failed to offer him the courtesy of explaining their actions to him. To the imam, whose ambitions were far wider than the confines of his endless war with the Ottoman state, the British represented a long-term threat. ${ }^{12}$ Of course, after 1915, the British were also aggressively supporting the imam's greatest rival, Muhammad İdrisi. The alliance İdrisi enjoyed with the British simply intensified Yahya's suspicions of British designs on the highlands, making subsequent British diplomatic overtures untenable. ${ }^{13}$ In the end, İdrisi and his growing power represented the most important reason for the imam's strong allegiance to the Ottomans and their large army. İdrisi's growing ideological legitimacy, and his reputation as an effective political alternative to the abuses of the imam's post-Da'an reign, became key factors in local politics and an irrepressible threat to the imam. ${ }^{14}$

\section{Tribalism at War: Muhammad İdrisi}

I will explore the impact of a rebellious Sufi order-the İdrisiyya-and its leader, Muhammad İdrisi, in the northern tier of the Yemen Vilayet ('Uthman Abāzah 1979, p. 196), in order to better demonstrate the fluidity of Yemeni social and political history. İdrisi's residence in the 'Asir probably represents the single most important catalyst to Yemeni politics during the war. İdrisi's impact on highland politics-the assumed zone of influence of the Zaydi imam-is clear when one begins to follow the terms of contention between Imam Yahya, the spiritual and political claimant to power of a highly fragmented Zaydi community, and other paramount figures in highland

12 For British attacks on northern Yemen well before World War I, see BBA İradeler-i Hususi 63/20 S.1324.

13 A letter from the imam states that some unspecified tribes were conducting negotiations with the British. Such meetings clearly inspired fear in the imam, accentuating the value of the Da'an accord with the Ottoman state. Dated 1335. (Abu Ghanim 1990, p. 491).

14 Letter from Sultan 'Ali bin 'Ali of Abdali, 19 August 1914, No. 119, to Colonel H. F. Jacobs in 33rd Weekly letter from Aden Residency, PRO FO $78 / 53785$. 
politics. Put simply, the regional rivalry over political resources between Idrisi and the imam empowered those local elites who were able to play off the rivals' political aspirations.

Idrisi came from a long line of successful Sufi leaders who established firm links throughout the Red Sea area and with branches as far away as Istanbul. Muhammad al-Kutb and his son 'Ali b. Muhammad settled along the 'Asir and Tihama coast when the Ottomans were making significant inroads in the first half of the nineteenth century (O'Fahey 1990, p. 114). The İdrisiyya settled in a region that historically resisted Zaydi hegemony. This area proved conducive to the organizational and spiritual capacities of someone like Muhammad İdrisi. While İdrisi represented a minority Sufi order and almost certainly came from a racially mixed background, his ability to put a stop to inter- and intra-"tribal" feuds and rampant banditry, securing the tranquility necessary for both a solid opposition against the Ottoman state and, more important, an economic environment that generated wealth, procured for him the affection (and often the allegiance) of shaykhs throughout the vilayet. ${ }^{15}$

While considering at length the political rivalry between the Ottomans and İmam Yahya on the one hand and İdrisi on the other, we must not lose touch with the larger geographical context. The Red Sea should be seen as an economic trade zone, much like the Indian Ocean, that played an important role in creating İdrisi's core alliance (Chaudhuri 1985, pp. 12-15). The first contributing factor to İdrisi's success must be the economic benefits accrued to those who joined forces with him. During the war, İdrisi's ports were the only ones with commercial access to this larger economic zone. The competitive advantage for İdrisi's allies was significant, and the potential wealth certainly attracted many to his camp.

The analysis of Idrisi's economic strengths is important in order to elaborate on the dynamics of domestic politics during the war. The consequences of a British naval blockade were quite severe in many parts of the highlands. ${ }^{16}$ Not only did Idrisi earn important revenue

15 İdrisi unabashedly reflects on his successes in his Bayän published in 1912. Bayān li-l-nās wa-hudà wa-maw'iza li-l-muttaqin. Reprinted and translated in Bang 1996, pp. 145-88).

16 A document from the office of İmam Yahya to one of his generals speaks of the ill effects of the blockade on the local economy. This document reflects the general malaise of the region and indicates the effects of Idrisi's challenge on Imam Yahya's ability to sustain hegemony in his traditional area of control. Dated 5th of Muharram, 1333 (In Abu Ghanim 1990, p. 539). 
from port fees and duties, but also the realities of being the sole outlet for trade attracted many from the interior highlands (for obvious reasons). Of central importance to İdrisi throughout the war was his ability to patronize many members of the Hashid and Bakil, the two largest tribal confederations identified in ethnographic work, which were located in the highlands geographically closest to him. They earned their income from trade as well as from direct British support. This monopoly on access created important links with coastal and highland merchants, who asserted their own claims to political power in Yemen. In conjunction with the immediate commercial links to Red Sea commerce, direct and amicable relations with 'Aden guaranteed lucrative provisioning duties for those allied with İdrisi. ${ }^{17}$

It was certainly helpful that the imam himself was not particularly astute at this game. His notorious stinginess alienated many, and ideological and familial attachments lost importance in a veritable freefor-all during the war. One may speculate that as time passed and news of Iddrisi's wealth and influence spread, the imam's unwillingness to pay his allies led to the many defections noted in British intelligence reports. ${ }^{18}$

While economic matters remained important throughout, they were not the only factors responsible for İdrisi's success. There is a complicated interchange of prestige vested in the militarily and financially powerful, and, as Steve Caton demonstrates so well, elements of rhetorical persuasion are clearly at work (Caton 1987, pp. 77-102). Idrisi is reported to have personified the traditional Yemeni intermediary with the necessary oratory skills to arbitrate in local disputes. His persuasive skills certainly complemented his military and economic power and created a reputation that transcended the geographical limits of his political control.

His success and his reputation inspired many-even from as far away as Ta'izz-to identify with him as the spiritual leader of all Yemen. This is noteworthy, since prior to the Da'an accords, it was

17 Reports from British intelligence noted that local people knew they would be starving without the İdrisi ports remaining open, thus many saw İdrisi as the true savior, while Imam Yahya lost authority and support. Report from Political Resident, Aden, D. G. L. Shaw, Major-General, to Residency, Cairo. "The War: Egypt, Turkey," 18 October 1915, WO 95/163825.

18 Interview with Lieut.-Colonel İsma'il Efendi, commandant of Ta'izz Garrison, as reported by W. F. Bainbridge, 19 February 1919 (Ingrams 1993, vol. 6, pp. 401-9). 
widely reported that İdrisi was largely disliked by highland elites. While I am not confident that İdrisi was as isolated as is suggested in British reports, the dynamics of World War I certainly changed the local conditions in which political and ideological perceptions were made. A letter from a notable from the Ta'izz Sancak, reporting on conditions in Yemen, indicates that many endorsed evicting the Ottomans by providing direct manpower and moral assistance to Idrisi. The author of the letter justified this policy by pointing out İdrisi's success in other regions. ${ }^{19}$

Since the time of the Italian War, Idrisi had attracted an impressive list of supporters representing a cross-section of the vilayet's population. Interestingly, these relations were initiated when Imam Yahya and İdrisi were allies against the Ottomans (Sãlim 1971, pp. 162-63). After the Da'an accords, it appears that many elected to remain with İdrisi, abandoning İmam Yahya in direct reaction to the alliance he formed with Istanbul. While a more elaborate analysis of the micropolitics of the highland areas specific to this issue is needed, it is, nevertheless, safe to conclude that the political situation was contentious and in constant flux during the period. I suspect that, as a result, secondary and tertiary rivalries, unsatisfactorily translated in the literature as between Zaydism and Sufism, animated highland Yemen society at the time. Many lower-level shaykhs were able to assert greater local power through the patronage of the outside forces the war brought to the region. For Iddrisi's part, he was able to exploit the relative obscurity of future allies with a variety of credentials enhanced by the dynamics of internal tensions among Zaydi leaders, the coastal communities' sense of vulnerability, merchants' commercial needs, and a semi-permanently based Ottoman element that had an impact on all these factors.

It is interesting to note that quite a few of Idrisi's allies belonged to larger families with split allegiances (al-Hibshi 1983, pp. 411-13). Nephews of prominent northern families who traditionally held power for the imam, and even one of Imam Yahya's sons, came and fought for Idrisi against the imam. ${ }^{20}$ Again, political conditions in the highlands

19 "Our master and our ruler, the İmam al-Hadi Muhammad bin 'Ali al-İdrisi, has turned them [Ottomans] away in the Tihama." Quoted in Report to General Sir Reginald Wingate, High Commissioner, Cairo, from J. H. Stewert, Aden Protectorate, 13 October 1917 (Ingrams 1993, vol. 6, p. 189).

20 İdrisi also claimed to be holding a letter from İmam Yahya's oldest son, Ahmad, who requested assistance from Idrisi to overthrow the imam and assign 
appear to have been greatly stimulated by the emergence of multiple sources of stipends, arms, and prestige. For the ambitious youngster, poor uncle, or marginalized shaykh, İdrisi and the conditions that made him represented an opportunity to ascend in the social and political hierarchies of highland society.

Many influential shaykhs had larger aspirations than the political environment Imam Yahya had allocated for them. Individual influence only mattered in their immediate regions, often nominally under Imam Yahya's fiscal and political control. During the war, it appears that the imam's political skills were spent attempting to gather military support from loyal "tribes" to prosecute his domination over rebellious areas. The lack of documentary evidence of the imam's success during the war is suggestive of the general conditions of highland political life. ${ }^{21}$

İdrisi offered an outlet to the outside world, an opportunity for many to escape from the political isolation and domination of the imam or his most trusted allies. As was the case in Ta'izz, the opportunity to attach oneself to a larger force often provided the needed push for many in the northern highlands to break free of local hegemonies. Thus we observe, for instance, incidents in which the imam's tax collectors were attacked and the culprits fled to İdrisi-held territory. The imam's own capacity to enforce state powers granted in Da'an was greatly limited by the fact that the local power of many had been enhanced by their alliance with İdrisi. ${ }^{22}$

Despite İdrisi's impressive list of allies, there were no guarantees in Yemen. One of the more important examples of this reality originates from inside 'Asir, a region seemingly under İdrisi's control. Ibn al-Hajj, who commanded a sizable entourage, was a consistent thorn in Idrisi's side. ${ }^{23}$ Ibn al-Hajj, shaykh of al-Madhat, previously had

21 For instance, there is a copy of the imam's message dated 1335(?) to his general Hamid Abu Ghanim in reference to his campaign against rebellious Hashid tribes in the Su'a area (private copy).

22 While İdrisi was often labeled criminal from as early as 1906 (BBA DH.MUI 1-1/35 327.S.27), there is plenty of evidence that the Porte was willing to forgive and forget in return for a settled peace, as was customary in the case of repentant rebels. BBA DH.MUI 1-4/33 1327.L.23. I would add that these overtures to İdrisi may have pressured İmam Yahya to sign his own accord with İzet Pasha, lest he find himself isolated. DH. MUI 1-4/66 1327.L.8.

23 Report from Political Resident, Aden, D. G. L. Shaw, Major-General, to Residency, Cairo. "The War: Egypt, Turkey," 18 October 1915, WO 95/163825. The document incorrectly transliterates Ibn al-Hajj's name as Haig. 
been aligned with Idrisi but reportedly had been subordinated to Ibn Thawb, a rival, during the initial military campaigns against the Ottomans. The mediating elements of more money and a chance to exert revenge or even solicit greater rewards from İdrisi (reportedly, İdrisi had been trying constantly to entice Ibn al-Hajj back into his camp ${ }^{24}$ provided an impetus for many local players in this complex, ever-shifting rivalry. This example again suggests that the presence of an outside power willing to provide the necessary combination of military and monetary support limits any single claimant's capacity to dominate local politics.

An elaborate stipend system was key to maintaining a coalition in Yemen. The downside of such broad alliances was clearly the inevitable logistics and political tension that followed. In the end, İdrisi's own political success hampered his military capabilities. İdrisi was never able to overcome regional antagonisms, which ultimately manifested themselves when local leaders, each with his own agenda, massed in Jizan. His alliances were highly factionalized, often comprising enemies who fought among themselves on the outskirts of Jizan. İdrisi's plans to raise a joint army of Hashid and Bakil to fight in the Tihama exceeded reality. ${ }^{25}$ Early on, it became clear that the elements of Hashid and Bakil confederations aligned with İdrisi could not bè trusted to remain focused on fighting the Ottomans.

For the purposes of this paper, it is important to reiterate that throughout the period in question, many members of the Hashid and Bakil "broke ranks" with their Zaydi leadership after the Da'an accords and joined İdrisi, who benefited from an economic and political alliance with the British, who in turn controlled Red Sea trade. It could be said that the war provided a variety of profitable economic, social, as well as political opportunities for a plethora of actors who previously may have played an important role in Imam Yahya's claims to political power. In some cases, the war's impact on local economies-a subject woefully neglected in the literature-was exten-

24 Letter to Political Resident, Aden, from L. F. Nalder, 20 December 1917 (Ingrams 1993, vol. 6, pp. 92-96). In Yemen, the Ottomans often served as a bargaining tool for local leaders. Ottoman troops consisted of Arab auxiliaries, among whom were the partisans of Ibn 'Ali Tawwab, and the Wa'zat who followed Ibn alHajj. Wa'zat is reported to have sent letters to İdrisi professing that Ibn al-Hajj would come if paid. Report to First Assistant Resident in Aden from Major B. R. Reilly, 20 October 1917 (Ingrams 1996, vol. 6, p. 127).

25 Notes of an interview with Sayyid Mustafa İdrisi [sic] on 20 August 1917; report by Major Wood (?) (Ingrams 1996, vol. 6, p. 114). 
sive and transformative. War was the only means of earning an income for many in isolated highland areas. Whatever underlying ideological or cultural structure may have created the apparently socially cohesive units discussed by historians and social scientists alike, the conditions under study here reveal that those logics do not prove resilient in many cases. Food shortages-as well as the resulting disputes over land, water, and transit points-complicates the narrative of the period. Of course it would be dangerous to suggest that economic rationalism served as the sole inducement to defections from the imam, but the point is that İdrisi's main support came from those very ontologically constructed "others" we find so often in the literature.

\section{Identifying the Issue through Practice}

While İmam Yahya was supposed to have won wide-ranging autonomy from the Ottoman state after the Da'an accords, including the right to collect taxes, his ability to govern was on the whole disrupted by the shifts in local power spurred by new allegiances of other Zaydi leaders with an "outsider," Idrisi, at the beginning of the Great War. ${ }^{26}$ The stipend and British-supplied arms, in addition to İdrisi's other attributes, enticed many to abandon their assumed positions within Yemeni sociopolitical life: Zaydi shaykhs from a number of so-called tribal sections severed any nominal allegiance with the imam, their tribe, and often their immediate family during the course of the postDa'an period and acted virtually as mercenaries serving İdrisi's cause and, by default, the infidel British. ${ }^{27}$

It is important to note that there is ample evidence of such changes of allegiance occurring throughout Yemen's history, not just in times of war. In the period immediately following World War I, scores of examples of "tribes" jumping from one patron to another litter the history books (Zabāra 1956, 3, pp. 27-29, 76-90, 119; al-Shamāhi 1937, pp. 11214, 173; al-Jiräfi 1951, p. 237). The question, therefore, is not whether or not we find the shifting allegiances peculiar to the war years, but

26 Report to General Sir Reginald Wingate, High Commissioner, Cairo, from J. H. Stewert, Aden Protectorate, 7 September 1917 (Ingrams 1993, p. 179).

27 Such conditions, it should be added, were not dissimilar to much of Europe prior to the consolidation of state power. Historians of the Middle East should note the reluctance to use tribal analogies in European historiography despite the similarities in conditions: tribes are supposed to belong to historically backward societies. Such awareness should inform our reading of Yemeni history. 
rather to ascertain the bases of these alliances in the first place. I suggest that they are the same for those abandoning the imam during the period of 1911-18 as before the treaty. The problem lies in the analytical criteria with which we judge agency in the Middle East, and in Yemen in particular. I suggest that our fixation on the tribal idiom and its assumed allegiances obscures the nature of communal/individual interactions and unnecessarily taints our historical perspective, privileging a small section of Yemeni society at the expense of these frequent "anomalies." Cultural and linguistic tools of unity, which constitute the segmentary logic of most ethnographic work on the Middle East, fail to account for the micro-dynamics of individual acts. The vast literature in the Middle Eastern field has relied on the explicit use of the notion of tribalism to mark historical patterns unique to the non-Western world (Peters 1953; Serjeant 1982). For Yemen, Martha Mundy (1995, p. 5) has adequately identified this pervasive reality, articulating the epistemological pitfalls of the segmentary project for the reading of Yemeni history. ${ }^{28}$ However, important critical interventions such as hers have clearly failed to modify recent (and highly acclaimed) studies on societies that have been idealized by anthropologists as quintessentially tribal in nature (Shryock 1997).

It must be stated here that the discursive resonance of tribal models pervades even the Arabic-language literature on Yemen. Reasons for this are: (1) narrative styles are similar to European historiographic practices in that linear representations attempt to incorporate large segments of the population in highly reductive terms, such as raya, ulema, or tribe; and (2) the politics of history, especially in Yemen, has a great deal to do with how the tribal idiom is being continuously evoked today by historians of both conservative ideological backgrounds and those ideologically informed by post-1962 changes in Yemen. Yemeni historians of all ideological persuasions use "tribes" as a sociological term much as Weber would-to connote developmental, material, and intellectual regression or determinant, impermeable political networks (Abū Ghānim 1990, pp. 258-60; al-Maqramì 1991).

Attempting to identify specific actors at particular conjunctures through transcendent sociological identifiers such as the "tribe" obscures the internal tensions that erupt within the geographical and

28 I strategically problematize below the use of the category, tribe, as Paul Dresch, in particular, has used it in his brief treatment of the second Ottoman period in Yemen, 1878-1918 (1993, pp. 219-24) 
political boundaries of specified "tribes." It is within these internal tensions, which often contradict segmentary patterns, that we find the dynamics of history. Local actors are not dutifully attached to any one "tradition" of negotiation/interaction, as is so often imposed by anthropologists; rather, they adapt to conditions as dictated locally at a specific point in time, often contrary to ideal models articulated in imperial capitals or the libraries of leading social scientists. Furthermore, the anthropologist's deliberate categorization, reinforcing a social hierarchy, is a reductive act that often speaks of political realities contemporary to the social scientist, rather than any reliable historical window. Contemporary power struggles in Yemen have appropriated many symbols-from Nasser's Arab nationalism to liberal democracyand anthropologists arriving with a set of assumptions codified in the vernacular of the trade often condone the temporal settlement of claims to power within the community they study by negotiating their work through assumed hierarchies. The professional attachment to the shaykhs with whom an anthropologist spends his/her time in the field often distorts the social hierarchy on which the shaykh stands (Caton 1990, pp. 11-15). These shaykhs who inform, either directly or indirectly, the representation of their community, reify fictions of social hierarchies in favor of contemporary ascendants and act as a barrier to understanding the process of assertion, lending ultimate historical voice to parties who are reading the anthropologists' motivations through the shared language of tribalism.

It must be emphasized that the positions that the shaykhs claim are contested. The fact that they are under constant contestation leaves one to wonder how deeply pervasive honor (sharaf), for instance (a term upon which Paul Dresch is fixated), proves to be in face of the violence that determines its social parameters. In Mundy's suggestive representation of how the misallocation of blood money left a shaykh without vital support from a neighboring village, we see how communal decisions surrounding leadership do not necessarily occur at the point of a gun. But there is nevertheless, a criterion that the shaykh sets and then secures in face of challenges to his position of authority (Mundy 1995, pp. 33-36).

Paul Dresch, a highly influential Oxford-based anthropologist, depicts Yemeni society in organizationally helpful charts (Dresch 1993, pp. 75-116). Such methods of organizing Yemeni life in the highlands, incorporating section and subsection titles, tribal names such as 
Dhu Muhammad and the Arhab, and then confining them in universalistic confederations-the Hashid and the Bakil-seeks to answer the question raised in the literature of its tribal subjects: How is social order maintained? What is central to the concept of segmentation is social discursive uniformity, whether articulated in forms of ideology or in metaphors of honor. There are significant problems with these representations of human interchange, however. Conventions of honor do not maintain their all-encompassing claims in history. Throughout the period in question, familial and communal "bonds" are frequently shattered with acts of "deception" and "treachery." The empirical hierarchies and social traditions articulated by anthropologists do not correspond to the disparate, exclusivist acts of individuals. The case of İdrisi's impact on highland politics is clearly suggestive of other elements at play.

Dresch, a meticulous architect of segmentary structures, acknowledges that there are variations in the application of collective norms (Dresch 1986). But that is exactly where Dresch fails to capture Yemen's checkered historical reality. No structure can withstand the individual actions I have identified in my research. While Dresch attempts to contain the tribal system by situating the individual within geometrical abstractions, that individual acts through a multiplicity of transgressions that easily move beyond boundaries set in the mind of the outside scholar. ${ }^{29}$ The notion of collective normative bonding distorts the frequent rivalries between and within so-called tribes, villages, and families. In the shadows of a larger war from 1911 onward, members of Yemeni society attempted to effect change in standing structures (fluid in their own right) of internal hegemony by creating alliances along lines that often went beyond the units of analysis used by social scientists and historians of Yemen. So-called tribal and sectarian communities exhibit a propensity to move beyond, between, and through their identifying categories.

While some of the more theoretically informed work on tribes attempts to provide deeper nuance into the dynamics of social ordering and the application and social expression of power, the very use of such analytical units ties the author far too tightly to an unchanging category. It is for this reason that I take issue with Talal Asad's application of ideology in legitimizing unequal social relations, for this "dis-

29 See Dresch's utilization of diagrams to homogenize human events (Dresch 1986 , p. 315). 
tinctive" ideological order risks assuming universal validity in the conceptualization of social order (Asad 1972). As is the case in Yemen, the confining implications of that narrative just do not reflect the dynamism of daily life, which constantly shifts the parameters of power. The question of legitimacy raised by Asad is tied into the conceptualization of honor, which situates Dresch's work alongside those who harbor equally problematic fixations on, for instance, Middle Eastern cities as sociological units distinct from rural society (Gellner 1981).

Legitimacy is certainly an important question that in Yemen is often locked in a legalistic dichotomy between tribal "custom" and the educated elite's "tradition" (Dresch 1993, pp. 181-83). Rhetorically, Paul Dresch and others would prefer to identify Yemenis according to their tribal credentials, but should we be seduced by the application of tribal idioms as a confirmation of a primordial attachment that is somehow beyond individual agency and the impact of war? The fact that there were those in Ottoman Yemen whose decisions often broke down categories requires us to abandon the tribal coloration of our assumptions in order to allow us to sink deeper into the lives of these participants in day-to-day history.

Social boundaries were not fixed in the lives of Yemenis in the period under study. The parameters of alliances being built around and within the political spaces evoked in the literature and the archival material are in constant flux. For this reason, local histories are more helpful in studying Yemen, since contingent alliances based on local concerns determine Yemen's political life. It is within these processes that we ultimately can observe the vicissitudes of Imamate politics. This, of course, does not assume that identifying units such as the "Hashid" implies permanent invalidation. It is noted that on occasion there were defections from Idrisi orchestrated by those who had previously betrayed the imam but then returned, seemingly with few adverse consequences. ${ }^{30}$ The idiom of social practice strikes a different chord at different times, requiring that we do not apply assumptions based on a sociology of the tribe, but rather adopt an openness to read into events and actions taken by individuals and groups-indicators far more precise than universalizing categories.

30 BBA Meclis-i Mahsus İradeleri 1088-62/2.N. 1331 (Document 2). 


\section{Conclusion}

The underlying purpose of this paper has been to identify important methodological issues at play when exploring regions such as Yemen during World War I. Productive spiritual and tribal categories that are used to classify human groups connote closure, fixity, and experiential and political limits. The evidence presented here suggests that such dedication to segmentary groups or fraternal orders who profess hermetically sealed doctrines does not accommodate the lively environment that colors Ottoman Yemen. The very function of identifying units is to draw distinctions, a process negatively labeled "othering," which tends to freeze political loyalties, human agency, and time. Much like our increasingly sophisticated understanding of the hybrid qualities of human identity in the post-colonial world, so too our use of sectarian, racial, and organizational categories in the past should be amended (Canclini 1990).

As I hinted earlier, the impact of imperialism-with all its potentially disruptive influences in the form of military repression, economic dislocation, and accelerated cultural hybridity-deserves deeper, more nuanced research. Social scientists and historians of warfare and colonialism should move beyond the banal descriptions of the revolutionary impact of war and European colonialism, which connote structures that are fixed, by reflecting on the local changes that take place in such conditions (Skocpol 1979; Cole 1993). The case of Imam Yahya is evidence that suggests that the war did not, in itself, provoke social breakdown. The imam was already in dire straits. The treaty, which supposedly was signed by a weak imperial state and a locally dominant, religiously legitimated leader, actually speaks of deeper issues at play. The assumed position of the imam in Yemeni society (the very term imam as applied in the literature is a categorical abstraction) is dubious in face of research. The romance between sociological categories and those who evoke them has led to a completely false reading of the World War I period in Ottoman Yemen. Being imam does not preclude Yahya from political challenges that in the period of the war translated into armed contestation, often pitting the imam against his own sons in the search for power. Here the case of Idrisi, a textually marginal Sufi leader, plays an informative role in this attempt to reread Yemen's social history.

Work to date has failed to answer some of the most basic questions 
about Yemeni history during the Ottoman period, largely because it does not frame questions in new ways. In addition to being ignorant of Ottoman archival materials, the literature is ignorant of questions explored in other disciplines. I believe Yemen serves as an ideal case to inspire a reassessment of the Ottoman experience in all areas of the Empire and to challenge the uncritical application of academic conventions. By scrutinizing the imperial context and the part it plays in local political relations-stressing local identifications to challenge the myth of a limited number of cohesive analytical units and to identify the components of a multi-tiered social network that exerts a variety of forces-we may begin to be able to make sense of the complexities of local political and imperial power. This paper also hints at the potentially rich material we can discover if we begin to explore the impact of warfare on the population as a whole. As recent wars in Kosovo and Chechnya remind us, the upheaval of daily lives has traumatic, transformative effects on men, women, and children who are making history.

Unfortunately, we have little information on day-to-day conditions for those on whom Imam Yahya and the Ottoman Empire depended most-those not represented in the documents and vaguely characterized as the Yemeni people. What information we have comes from the anthropological work, which I have shown to be largely unwilling to break from past fixations. While Dresch himself notes a "tribe" lives not by force of its logic alone, but rather by acts of individuals, we are not yet capable of identifying those individuals from the forest we have created (Dresch 1993, pp. 96-97). If the tribe is vulnerable to the vicariousness of human politics, then what value do concepts such as honor or, even larger, national identity or religious affiliation, carry? Certainly they represent immediate, specific claims to an individual or collective identity, often juxtaposed to that "other," equally tied to such linguistic imperfections, but these representations are not fixed in time; they are specific, individual moments. What the anthropological labels attempt to do is fix the meaning of individual acts within the category, set as immutable and transcending time and space. It is our job as social scientists and historians to return the texture of the lives of those people who, less than a century ago in far-off Yemen, were entangled in complex ways with their fellow Ottoman citizens in Anatolia, Syria, and Albania and whose sons were dying on the Ottoman Empire's southern front. 


\section{REFERENCES}

Abou-El-Haj, Rifa'at. 1991. "Power and Social Order: The Uses of the Kanun," in The Ottoman City and its Parts: Urban Structure and Social Order, ed. Irene A. Bierman, Rifa'at Abou-El-Haj, and Donald Preziosi New Rochelle, N.Y.: Aristide D. Caratzas, Publisher, pp. 77-99.

Abu-Lughod, Lila. 1990. "The Romance of Resistance: Tracing

Transformations of Power Through Bedouin Women," American Ethnologist 17, pp. 41-55.

Ahmet İzzet Paşa. 1928. "Harb-i Umumi'nin Vuku' ve Ziya'nda Mes'uller ve Mes'uliyetler," Akşam.

Akarh, Engin. 1993. The Long Peace: Ottoman Lebanon, 1861-1920. Berkeley: University of California Press.

Akpınar, Alişan. 1997. Osmanlı Deuletinde Aşiret Mektebi. Istanbul: Göçebe Yayınları.

al-Akwa', Ismāōil b. 'Alì. 1980. al-Madāris al-Islāmiyya fí al-Yaman. Sana'â': Sana'á' University.

Anderson, Lisa. 1990. "Tribe and State: Libyan Anomalies," in Tribes and State Formation in the Middle East, ed. Philip S. Khoury and Joseph Kostiner. Berkeley: University of California Press, pp. 288302.

Anscombe, Frederick F. 1997. The Ottoman Gulf: The Creation of Kuwait, Saudi Arabia, and Qatar. New York: Columbia University Press.

Asad, Talal. 1972. "Political Inequality in the Kababish Tribe," in Essays in Sudan Ethnography, ed. Ian Cunnison and Wendy James. New York: Humanities Press, pp. 126-49.

1993. Genealogies of Religion. Baltimore, Md.: Johns Hopkins University Press.

Baldry, John. 1976. "Al-Yaman and the Turkish Occupation 18491914," in Arabica, vol. 23, pp. 156-95.

Bang, Anne K. 1996. The Idrisi State in 'Asir, 1904-1934. Bergen: Bergen Studies on the Middle East and Africa.

Blumi, Isa. 1998. "The Commodification of Otherness and the Ethnic Unit in the Balkans: How to Think About Albanians," East European Politics and Society 12, no. 3, pp. 527-69.

2000. "To Be İmam: Empire and the Quest for Power in Ottoman Yemen during World War I," Yeni Türkiye Dergisi (Osmanll). 
Caton, Steve. 1987. "Power, Persuasion, and Language: A Critique of the Segmentary Model in the Middle East," International Journal of Middle Eastern Studies 19, pp. 77-102.

1990. Peaks of Yemen I Summon: Poetry as Cultural Practice in a North Yemeni Tribe. Berkeley: University of California Press.

Chaudhuri, C. H. 1985. Trade and Civilization in the Indian Ocean: An Economic History from the Rise of Islam to 1750. Cambridge: Cambridge University Press.

Cole, Juan. 1993. Colonialism and Revolution in the Middle East. Princeton, N.J.: Princeton University Press.

Davison, Roderic. 1963. Reform in the Ottoman Empire, 1856-1876. Princeton, N.J.: Princeton University Press.

Domani, Beshira. 1995. Rediscovering Palestine: Merchants and Peasants in Nablus, 1700-1900. Berkeley: University of California Press.

Dresch, Paul. 1986. "The Significance of the Course Events Take in Segmentary Systems," American Ethnologist 13, no. 2, pp. 309-24. 1993. Tribes, Government and History in Yemen. London: Clarendon.

Echenberg, Myron. 1991. Colonial Conscripts: The tirailleurs sénégalais in French West Africa, 1857-1960. Portsmouth, N.H.: University of New Hampshire Press.

Eickelman, Dale, and James Piscatori. 1990. "Social Theory in the Study of Muslim Societies," in Muslim Travellers, ed. D. Eickelman and J. Piscatori, Berkeley: University of California Press.

Findley, Carter V. 1980. Bureaucratic Reform in the Ottoman Empire: The Sublime Porte, 1789-1922. Princeton, N.J.: Princeton University Press.

Gellner, Ernest. 1981. Muslim Society. Cambridge: Cambridge University Press.

Abū Ghānim, Fadīl 'Alī Ahmad. 1990. al-Qaỉbla wa al-Dawla fí alYaman. Sana'â': Dār al 'Anād.

Glaser, Eduard. 1884. "Meine Reise durch Arhab und Haschid," Petermann's Mitteilungen 30, pp. 170-83, 204-13.

Gramsci, Antonio. 1971. Selections from the Prison Notebooks, ed. and trans. Quintin Hoare and Geoffrey N. Smith. New York: International Publisher.

al-Hibshi, Muhammad. 1983. Masādir al-fikr al-'Arabi al-Islāmi fi alYaman. Sana'ā’: Markaz al-Dirāsāt al-Yamaniyyah. 
Ingrams, Doreen, and Leila Ingrams, eds. 1993. Records of Yemen, 1798-1960. 6 vols. London: Archive Editions. Vol. 6.

al-Jirāfi, 'Abdullāh b. 'Abd al-Karìm. 1951. al-Muqtātaf min ta'rikh alYaman. Cairo: 'Isā al-Bābi al-Halābi.

Kreiser, Klaus. 1989. "Abdülgani Seni: Ein aufgeklärter Imperialist im Jemen (1909-1910)," Jemen-Report 1, pp. 11-15.

Kruse, Hans. 1984. "Takfir und Jihad Bei den Zaiditen des Jemen," Welt des Islams 23-24, pp. 424-57.

Lenci, Marco. 1990. Eritrea e Yemen: Tensioni italo-turche nel mer Rosso, 1885-1911. Milano: Franco Angeli.

Maier, Charles S. 1975. Recasting Bourgeois Europe. Princeton, N.J.: Princeton University Press.

Mandaville, Jon. 1984. "Memduh Pasha and Aziz Bey: Ottoman Experience in Yemen," in Contemporary Yemen: Politics and Historical Background, ed. B. R. Pridham London: Croom Helm, pp. 20-33.

'al-Maqrami, Abd al-Mālik. 1991. al-Ta'rikh al-ijtimä’i lì al-thawrah alyamanìyya. Beirut: Dār al-Fikr al-Mu'āsir.

Mehra, R. N. 1988. Aden and Yemen (1905-1919). Delhi: Agam Prakashan.

Meissner, Jeffrey. 1987. Tribes at the Core: Legitimacy, Structure and Power in Zaydi Yemen. Ph.D. diss., Columbia University, New York.

Muhtar Paşa, Gazi Ahmed. 1996. Anılar: Sergüzeşt-i Hayatımın Cild-i Evveli. Istanbul: Tarih Vakf Yurt Yayinları.

Mundy, Martha. 1995. Domestic Government: Kinship, Community and Polity in North Yemen. London: I. B. Tauris Publishers.

O'Fahey, Robert S. 1990. Enigmatic Saint: Ahmad Ibn Idris and the Idrisi Tradition. Evanston, Il.: University of Illinois Press.

Peters, Emrys L. 1953. "The Proliferation of Segments in the Lineage of the Bedouin of Cyrenaica," Journal of the Royal Anthropological Institute 40, pp. 29-53.

Prakash, Gyan. 1995. "After Colonialism," in After Colonialism: Imperial Histories and Postcolonial Displacements, ed. Gyan Prakash. Princeton, N.J.: Princeton University Press, pp. 3-17.

Raggio, Osvaldo. 1986. "La politica della parentela: Conflitti locali e commissari in Liguria orientale (secoli XVI-XVII)," Quaderni storici, vol. 21, pp. 721-57.

Rogan, Eugene. 1996. “Aşiret Mektebi: Abdülhamid II’s School for 
Tribes (1892-1907)," International Journal of Middle East Studies 28, pp. 83-107.

Sãlim, Sayyid Mustafã. 1971. Takwin al-Yaman al-Hadith: al-Yaman wa al-Imām Yahyā, 1904-1948. 4th ed. Cairo: Ma'had al-Buhuth wa-l-Dirāsāt al-'Arabiyya.

Serjeant, Robert.B. 1982. "The Interplay between Tribal Affinities and Religious (Zaydi) Authority in the Yemen," Al-Abhath (Beirut) 30, pp. 11-50.

Skocpol, Theda. 1979. States and Social Revolution. New York: Cambridge University Press.

al-Shamāhi, 'Abdullāh. 1937. Sirat al-'Arifin ilā Idräk Ikhtiyārät Amir al-Mu'minin. Sana'â': Matba'at al-Ma'arif.

al-Shimāhi, Qādi 'Abdallāh b. 'Abd al-Wahāb al-Mujāhid. 1984. alYaman: al-Insān wa al-Hadärah. Beirut: Minshurātal-Madinah.

Shryock, Andrew. 1997. Nationalism and the Genealogical Imagination: Oral History and Textual Authority in Tribal Jordan. Berkeley: University of California Press.

Tutwiler, Richard. 1987. Tribe, Tribute and Trade: Social Class Formation in Highland Yemen. Ph.D. diss., SUNY at Binghamton. 'Uthmān Abāzah, Faruq. 1979. al-Hukm al-'Uthmāni fi -al-Yaman. Beirut: Dār al-'Awwada.

1987. 'Adin wa al-Siyāsa al-Britaniyya fí al-Bahr al-Ahmar, 1839. 1918. Cairo: al-Miya al-Misriyya al-'Asāma li al-Maktāb.

al-Wãsi'i, 'Abd al-Wāsi'. 1928. Ta'rikh al-Yaman. Cairo: al-Matba'at alSalafiyya.

Zabāra, Muhammad b. Muhammad. 1956. Á'immat al-Yaman bi alQarn al-Räbi' 'Ashar. 3 vols. Cairo: Matba'at al-Salafiyya. 